\title{
Dilemmas of tax-inducted location decisions
}

\author{
Michał Sosnowski \\ Wroctaw University of Economics \\ Poland \\ m.sosnowski@onet.eu
}

\begin{abstract}
In this paper the author discusses the problem how tax setting by governments may change the terms of competitiveness between countries and induce firms to initial location decisions. Here is important the question how direct tax coordination within the European Union will affect the tax competition and the development of national economies. According to the author, any attempt at harmonization of tax policies done in an arbitrary way, contrary to the freedom of economic activity, and consisting in harmonizing income tax rates through setting up a minimum rate or rate brackets would be harmful to growing economies and might pose a real threat to economic development. On the other hand, the some current proposals CCCTB (common consolidated corporate tax base) could make tax regimes more transparent without limiting the conditions of tax competition.
\end{abstract}

Keywords: fiscal policies, tax competition, tax harmonization, relocation, EU countries

JEL Classification: F20, H25

\section{INTRODUCTION}

Globalization, both social and economic processes, is a progressing phenomenon. More and more freedom in the movement of capital and people is an additional factor strengthening is intensity.

Unquestionable positive effects of globalization are the transfer of technologies between countries, dissemination of scientific knowledge and the acceleration of technological progress.

In addition, there is an increase in trade (Thompson, 2007; Rodrik, 1998; Gilroy, 2001) based on comparative advantage, cross-border investments, institutional development, the competitiveness of individual companies and entire economies, as well as other desirable for societies, regional and national consequences arising from the more creativity of people in the world disappearing barriers and boundaries. Of course, one can not disregard some negative effects that may affect countries at the periphery of the importance of government, as well as beyond the sphere of economic interest of investors (Stern, Deardorff, 2006; Boyce, 2004). Moreover, the negative sign of globalization may be damage to the environment as a result of excessive (often predatory) the exploitation of natural processes, the intensity of migration in search of an attractive working and living conditions, loss of (partial) state sovereignty in favor of supranational structures and cultural identity in favor of unification patterns of behavior or lifestyle. 
In this context, it is also important the issue of relocation (migration) of a company and its causes as a natural process in an era of increasing globalization, and just as globalization, exerting a significant influence on the economic and social life in the micro- and macroscale.

The purpose of this article is to present the issues relating to the relocation of companies in terms of striving for optimal income taxation by using tax competition. Furthermore, this article is intended as an attempt to the response to the still relevant question: what is the importance of the relocation process for the economies, for whom is it more potential opportunity, and for whom it may pose some risk due to the dynamic development and increase competitiveness in the globalizing world. The European Union heads down path toward a more complete integration. Constantly, although to varying degrees, in the public debate is discussing the problem of more advanced harmonization of tax policies within the European Union. This article tries to offer a plausible answer to the question of what style of such harmonization could offer new opportunities to the economies. Still important question remains how the fulfillment of that postulate will affect in the future the economic development of EU countries, the level of their competitiveness in the global economy and how to harmonize tax systems to make it to the benefit of EU economies.

Nature of business relocation

Relocation is a form of adaptation to a changing business environment. In the literature one can find three main causes of migration enterprise: 1) internal factors (status, ownership, size, age, employment growth, acquisitions, mergers, acquisitions), 2) factors related to the location (location of company headquarters, the type of industrialization and characterization objects), 3) external factors (market size, labor market issues, government policies and general economic conditions) (see van Dijk, Pellenbarg 1999; 2000). While the list of internal factors is almost complete, knowledge about the external factors is not exhaustive. Full knowledge of these particular factors may be crucial to explain the reasons for the migration of enterprises (Brouwer, Mariotti, van Ommeren, 2002).

According inter alia to Leo Sleuwaegen (Pennings, Sleuwaegen, Monmaerts, 2000), nature of the relocation changes over time. Decades ago, the phenomenon was somewhat reflected the life-cycle model. The production of some goods after reaching the peak phase of the growth cycle was transferred from the more developed countries to less developed countries, which prolonged the life expectancy of these products and ensure profitability. But now, the significance of economies of scale, and the process of globalization and greater flexibility in the operation of enterprises, result in the formation of transnational corporations.

The development of business and the need for adequately large space for the production represents here the main drivers for the migration. When an entity reaches the limits of its capacity is somehow forced to relocate their activities. Another reason for the relocation is cost optimization, therefore companies use all circumstances and are looking for other places conditions, which are favorable, e.g. using economies of scale, improved access to raw materials and energy sources, differences in the level of wages, raw material prices and energy, as well as any incentives made by local authorities.

Companies are motivated by a specific government policy using fiscal instruments, including grants, low taxes, tax etc. It should be emphasized, that this strategy was used by the authorities in most industrialized countries since the 50s 20th century, mainly in order to reduce income disparities between regions and employment growth. Here one can mention the following types of migration enterprise (Małuszyńska, 2006, p. 3):

- integral migration - the whole company moves to a new place, and partial migration - part of the company is transferred to another location for a period of reconstruction/development,

- the permanent or temporary migration - the entire company or a part thereof is transferred to another location for the duration of reconstruction/extension, 
- vertical migrations - the company moves from the big city to the suburbs or to a smaller town, and horizontal migration - the company moves to another city or another area of the same rank,

- inter-regional, intra-regional or international.

The relocation process is manifest in the transborder flows of foreign direct investment (FDI). The actual scale of this phenomenon is hardly measurable, the difficulty lying inter alia in the fact that relocation functions alongside offshoring and outsourcing. Due to the disparity between the economies of the EU Member States, and between that of the EU as a whole and those of Asian countries, there are certain factors that encourage company relocations: cheaper supply, tax advantages, potential access to new markets, technology and lower labour costs. The relocation process manifests itself in the form of international flows of FDIs, but the actual scale of this phenomenon is difficult to measure. The reason for this difficulty lies in the fact that in addition to the concept of relocation also operate offshoring and outsourcing concept. The relocation of the enterprise would be rather identified with the transfer of production existing in the other place, which is associated with job losses at existing operations. However, determination of offshoring and outsourcing is not clearly indicated (Małuszyńska, 2006, p. 4). Offshoring is understood as the transfer of production (or procurement) of the country where the company is located in another country, usually characterized by lower labor costs. This phenomenon may, but need not, take place within a company.

However, the phenomenon of outsourcing is the contracting out of a business process to a third-party (Kawecka-Wyrzykowska, 2007). Relocation thus provides both a simple production function (offshoring) transferred to countries with more favorable economic conditions, as well as services and other activities carried out so far in the home country of the investor (highly developed economies). These activities are aimed at maintaining competitive advantage by corporations globally. They decide to deepen expertise in key strategic activities for the company while releasing and giving out less significant strategic actions. Outsourcing these activities on behalf of another, cooperating, specialized in the field of the company allows enterprises to significantly reduce operating costs. This results not only from the lower rates offered to the workforce, but also to make better use of information and communication technologies that enable the collection, processing, transmission, and flexible delivery services to the customers in remote locations around the world, in terms of work for two or three shifts and different time zones (Wdowicka, 2009).

In the opinion of the European Economic and Social Committee (EESC) relocations can be estimated due to the positive and negative consequences associated with it. Moreover it should be mentioned that relocation of industrial production can, at best, help to promote social rights in countries receiving investment and necessarily involves the regular transfer of know-how; consequently relocation can make a considerable contribution to further increasing the competitiveness of the relocated businesses (European Economic and Social Committee Opinion, 2005).

The analyzes also show that the assumption underlying the criticism of relocation, it's not always true, and the scale of the impact of relocation phenomenon is exaggerated. So that the "export" of jobs to lowcost countries, to which production is transferring, contributes to the rise in unemployment in European countries. The jobs moving overseas doesn't have to mean the loss of jobs in developed countries. On the contrary, it may be even increase the number of jobs in the home country, because foreign subsidiaries are not necessarily in competition with national production company, but often they're complementary to it and help improve the efficiency, quality and reduce production costs, which results in increased sales. This may lead to increased employment in the home country. However, an advantage in attracting new investment and jobs are mainly those countries which produce at competitive prices (Mankiw, Swagel, 2005).

It should be noted that relocation to countries with low wages and low skills are very limited scope in terms of the whole economy. The negative impact of competition from low-wage countries is concerned especially at the low qualifications (Gorter, Tang, Toet, 2005). According to the European Commission 
report on employment, nearly three quarters of the total number of jobs lost due to internal restructuring, more than 13 percent is the result of bankruptcy or closure, 3 percent is the result of mergers and acquisitions, and for more than 7 percent be attributed to relocation of production activities, including 2.5 percent attributable to outsourcing. Similar assessment of the scale of relocation due to the UNCTAD study. The majority of relocation takes place within individual countries, and the migration of business on an international scale covers only 1-2 percent of cases. However, the negative effects would be rather linked to the relocation outside the EU, particularly, when the relocation phenomenon, apart from being the direct cause of job losses, could also bring other, associated problems, such as an increase in social security costs for governments, increased social exclusion, lower tax revenues to the budget and less economic growth overall, partly as a result of a general demand shortfall. In addition, European companies may be somewhat forced to compete with companies with lower costs. This reduces the pressure to increase spending on R\&D and the effect of reducing their potential for innovation. Assuming that it's inevitable occurrence of the relocation, the EESC believes that the best way of tackling the understandable concerns over the negative consequences of company relocations is to develop and properly implement social policies that promote a positive attitude to change, enable workers to adapt and upgrade their skills, and encourage job creation (Employment in Europe 2004, 2004).

All in all, the relocation process should be beneficial for the whole global economy. Firstly, it makes the highly developed countries get rid of the less advanced sectors of economy and utilize their highly skilled labour more efficiently in the high-tech industries - the use of comparative advantages will facilitate their sustainable economic growth and welfare. Secondly, the host countries gain not only new jobs, but also an increased inflow of FDIs and know-how, thus securing their own economic growth. One can only have some concerns if the process of relocation refers to the business, which was financed with public funds, especially from the EU funds under cohesion policy. This was, incidentally, reflected in legislation restricting the use of the Structural Funds (cf. Council Regulation (EC) No 1260/1999 and Council Regulation (EC) No 1083/2006).

\section{TAX HARMONIZATION AND TAX COMPETITION IN THE EU}

Harmonization of fiscal policies is a consequence of a larger process - the progressive economic integration of the European Union member countries. The original objective was to coordinate the fiscal policies of individual EU countries. This involved bilateral and multilateral consultations between them and the execution of agreements on tax cooperation and on the taxation types and levels to be applied. According to Jan Głuchowski, tax harmonization '... constitutes a compromise between the low level of coordination and the ideal level of standardisation (the same tax system, very similar tax base and rates)'(Brzeziński et al., 1998). Lekoadia Oręziak echoes him in claiming that tax harmonization may be defined as '... a mid-way solution between a loose, non-binding coordination of national taxation rules and their unification in all the member countries' (Oręziak, 2007). Tax harmonization is usually interpreted as the process of unifying separate tax systems to eliminate the fiscal barriers which may distort the free movement of goods, services and factors of production within a uniform market (Kopits, 1992).

This leaves us with the still pending question what style of tax harmonization would offer those countries developmental opportunities and what would pose a threat - if our primary concern is the need for socio-economic development and competitive advantage in the globalising world of economy. Tax policy set to reduce tax rates seems a very reasonable one, provided that it leads to the overall diminishing of tax burdens, made up of not only rates but also other elements of the tax system structure. Douglas Holtz-Eakin 
and Harvey S. Rosen demonstrated that raising the tax rates results in a slow-down in business activity as companies accumulate less capital and create fewer jobs (Holtz-Eakin, H.S. Rosen, 2001). Their study covered the years 1985-1988 and thus managed to embrace the outcomes of Ronald Regan's tax reform.

Proceedings taxpayer may bring, among others, to legally optimize the level of taxation through the use of flexible tax structure or by tax migrating to countries with lower tax weights, taking advantage of the tax competition between countries. Creation of a stable framework for business activity and supporting the investment and developmental projects become more and more important today as globalisation of economic processes eliminates those who cannot keep up with their competitors and gain a sustainable competitive advantage.

Countries with relatively inefficient tax systems can experience significant welfare losses if, as a byproduct of financial integration, they find themselves competing over capital income taxes against countries with relatively efficient tax systems (Mendoza and Tesar, 2005).

Business activity is profit-oriented by nature, and every tax burden means a reduction in the present or future capital assets of taxpayers. With regard to the corporate income tax, direct taxation reduces the scale of either consumption or business expenditure. Therefore the natural taxpayers' response is avoidance of such consequences of taxation or the drive to at least minimise its negative impact. The taxpayers' responsive behaviour may involve tax optimisation within the limits allowed by law, i.e. making use of the tax structure flexibility, or tax-driven migration, frequently referred to as relocation (Leamer, 1996), i.e. moving the operations to another country.

After the common currency was adopted by some EU members, taxation became one of the last economic instruments in the hands of the local and national governments for stimulating the domestic and foreign investments and setting tracks for economic developments within their territory. The aforementioned factors must be considered in the context of the economic situation of the countries which underwent an economic transformation. The new EU members are generally at a lower level of economic development and can offer fewer incentives to the potential investors than the EU-15. The European Union has no uniform tax system in place for all the 28 member countries, which means just that each nation runs its own tax policies.

While with such indirect taxes as value-added tax (VAT) or excise we can already speak about an advanced harmonization process, despite the still existing differences between individual countries in the construction of these taxes, with direct taxation the harmonization process is nowhere that advanced and still in its cradle. There are fundamental differences e.g. in defining the tax base through different accounting rules, in the approaches to capital gains, in different definitions of depreciation or - last but not least - in the tax rates. All those differences sum up to make the effective tax burden on corporate income much different.

It is a fact that a diversification of tax systems, especially with regard to corporate income, requires companies to apply a significant range of knowledge and know-how to be able to function amidst the several tax systems operated within the European Union, which for smaller companies means huge extra costs and frequently undeserved losses. According to the calculations presented by Karel Lannoo and Mattias Levin of the Centre for European Policy Studies (CEPS), the corporate cost of compliance with individual countries' tax regulations may be as much as 2 to 4 percent of total tax revenues, or between 4 and 8.6 billion euro EU-wide (Lanoo, Levin, 2002). On top of that, there is the cost of time spent on searching for available tax reliefs, tax havens and tax bonuses - the time that might be as well spent on working out truly innovative approaches and methods of production or services.

A road map for harmonization of direct taxation was set by the Ruding Committee Report of March 1992 ( Report of the Committee of Independent Experts on Company Taxation, 1992). The Report exposed huge differences in taxation of corporate profits between individual countries and their distortive effects for 
the operation of the Communities internal market and competition, as they were factored in while deciding investment locations. The subsequent EU activities towards stronger harmonization of member countries' corporate taxation policies was development of the Code of Conduct for Business Taxation, adopted by the Council of Economics and Finance Ministers (ECOFIN) on 1 December 1997. The Code is a collection of guidelines meant to limit the harmful tax competition and especially tax avoidance and tax frauds.

The outcome of the discussion initiated by the Ruding Committee Report are the solution proposals, successively put forward since March 2001. First of all, the solution proposed for the SMEs operating transnationally in Europe consisted in the application of the home state's method of calculating the tax base (HST - Home State Taxation) for the sum total of their internationally earned income. The HST concept was first proposed by Sven-Olof Lodin and Malcolm Gammie (Lodin, Gammie, 1999).

Another solution proposed was to determine a common consolidated corporate tax base (CCCTB) (Towards an Internal Market without tax obstacles, 2001). The EU multinational corporations would have an option of profits consolidation. If operations in one country bring profits and those in another one do not, the profits would be set off with the losses and tax would be levied on the net gains. Should the CCCTB concept be adopted EU-wide, tax rates would become the primary and transparent criterion for the investors to assess the attractiveness of any given territory.

Business operating across national borders will benefit both from the introduction of crossborder loss compensation and from the reduction of company tax related compliance costs. Allowing the immediate consolidation of profits and losses for computing the EU-wide taxable bases is a step towards reducing overtaxation in cross-border situations and thereby towards improving the tax neutrality conditions between domestic and cross-border activities to better exploit the potential of the Internal Market. Calculations on a sample of EU multinationals shows that, on average approximately 50 percent of non-financial and 17 percent of financial multinational groups could benefit from immediate cross-border loss compensation (Council Directive on a common consolidated corporate tax base, 2011).

A major benefit of the introduction of the CCCTB will be a reduction in compliance costs for companies. Survey evidence points to a reduction in the compliance costs for recurring tax related tasks in the range of 7 percent under CCCTB. The reduction in actual and perceived compliance costs is expected to exert a substantial influence on firms' ability and willingness to expand abroad in the medium and long term. The CCCTB is expected to translate into substantial savings in compliance time and outlays in the case of a parent company setting up a new subsidiary in a different Member State. On average, the tax experts participating in the study estimated that a large enterprise spends over $€ 140,000(0.23$ percent of turnover $)$ in tax related expenditure to open a new subsidiary in another Member State. The CCCTB will reduce these costs by $€ 87,000$ or 62 percent. The savings for a medium sized enterprise are even more significant, as costs are expected to drop from $€ 128,000$ ( 0.55 percent of turnover) to $€ 42,000$ or a decrease of 67 percent (Council Directive on a common consolidated corporate tax base, 2011).

It should be noted, however, that there is much emphasis on applying a relatively wide tax base with simultaneous reduction of preferential taxation (Implementing the Community Programme for improved growth and employment and the enhanced competitiveness of EU business, 2007; Request of input from national tax administrations for the Impact Assessment of the reforms at the EU level of corporate tax systems, 2008). Besides, a uniform tax base would bring huge changes in the taxation of multinationals. Today taxes are levied by the corporations' home countries. With the application of the CCCTB concept, tax revenues would be split among the countries where such a corporation runs its business while the general tax amounts paid by multinationals would decrease. His new system would also have a significant impact on CIT revenues earned by individual countries - there would be both winners and losers. 
The simulations presented in the report prepared by Ernst\&Young in February 2011 (the report was ordered by the Irish Department of Finance to assess the potential impact of CCCTB introduction on GDP, employment and business activity) lead to the conclusion that the largest loss of tax revenues would be faced by Denmark ( 8.3 percent), the Netherlands ( 7.5 percent) and Ireland ( 5.5 percent). For Poland, tax harmonization based on the CССТB concept would mean just a minimum loss of tax revenues. The largest increase in budget income would be enjoyed by France (+6.0 percent), Greece (4.0 percent) and Latvia (3.8 percent). In accordance with the report, the new system would bring about numerous relocations, resulting in significant job losses. In this respect, the biggest losers would be Ireland (rise in unemployment by 1.2 percent), Luxembourg (1.1 percent) and Poland (1 percent, i.e. about 160,000 jobs). The winners would be France (rise in employment by 0.4 percent), Spain ( 0.1 percent) and Belgium (0.1percent) (European Commission and the CCCTB. Hard work ahead, 2011).

It should be emphasized, however, that a straightforward comparison of nominal CIT rates is merely a starting point for any comparative analysis of national tax systems and does not offer a complete picture of their actual arduousness to companies. This is so because individual countries calculate the tax base in different ways. There are many sources of such differences: the range of costs qualifying as business expenses, the depreciation method applied, the method of reserves creation and accounting for losses, the applicable tax reliefs and credits and so on.

Therefore, getting a complete picture requires the use of effective rather than nominal tax rate for comparison. It is only the more favorable effective tax rate that may induce businesses to move their operations as foreign direct investment into countries offering less burdensome taxation. So, the introduction of the CCCTB concept significantly would facilitate the comparison of the tax burden between countries.

The conclusions relating to tax policy states that developing a common corporate tax base could be a revenue neutral way forward to ensure consistency among national tax systems while respecting national tax strategies, and to contribute to fiscal sustainability and the competitiveness of European businesses. The clou is that none of the forms of harmonization should destroy the healthy competition between countries, including the tax competition.

Healthy competition leads to streamlining the fiscal policies of competing countries and to the creation of a business-friendly atmosphere. The competition for investment capital is not a zero-sum game which must have its winners and losers, especially in long-term perspective. The competing parties behave rationally in their efforts to secure the optimum environment for economic entities, increasing the efficiency of their public finance systems on the way. This should translate into improved living conditions of the population. Tax competition is a phenomenon which consists in the governments' applying fiscal instruments to increase the competitive advantage of their territories by attracting or keeping the capital engaged in economic activity. It should also be remembered that multinational corporations (see Dicken, 1998) are to a large extent motivated by their drive to reduce tax burdens applicable to their operations. Therefore, they appear highly sensitive to the level of taxes levied on their line of business in any given country (Devereux, Hubbard, 2000). Tax competition may be perceived as beneficial and may develop - per analogiam to business competition - to approximate the ideal competition (Tiebout, 1956) in which the countries or regions compete for mobile factors of production.

Observation of a process of tax competition allows one to distinguish two forms of this phenomenon (Sepp, Wróbel, 2003): crawling tax competition and - following the terminology of the European Commission - unfair tax competition. The first form involves a long-term, comparatively slow process where states are underbidding (as initiators or as reaction to the measures of the other players) the tax rates of their competitors in several rounds so that gradually the tax rates of all participating players are converging downwards. 
Crawling tax competition refer to regular tax systems and usually concern all investors regardless whether they are domestic or foreign (Krajewska, Krajewski, 2007). Of particular relevance is direct tax competition for foreign direct investment (FDI) and portfolio investment (PFI) via reductions in the nominal corporate tax rates, but also the introduction of dual income tax systems in several member countries to privilege capital incomes (Schratzenstaller, 2000).

The unfair tax competition comprises isolated attacks of single states with the only aim to undercut the other states in the direct competition for foreign investment; therefore it is sometimes called "tax dumping" (Grigat, 1997).

Besides, we should remember that tax burden is just one of several reasons for transferring production to another country (Gryko, Kluzek, 2008), and not the most important one at that. The business attractiveness of any country has numerous aspects, including the levels of social security, transport costs, infrastructure development, labour education or the condition of natural environment (Economic and Social Committee Opinion On Direct company taxation, 2002). The main factors are invariably the cost and quality of labour as well as the size of markets and the distance from key customers. It is only when those non-fiscal factors look favorable that the tax burden really comes into play.

The independent decisions taken by individual OECD and EU countries during the recent decades brought about a general trend towards reducing the corporate income tax rates, which reflects the urge to achieve or maintain their competitive advantage in the globalising world. During the 1995-2014 period, the EU-wide average rate of corporate income tax went down by 12.6 percentage points (i.e. by almost 36 percent) - and it was in just 19 years! Apart from Malta, all the EU countries reduced their CIT rates, with the most significant reductions applied in Bulgaria ( $-30 \mathrm{pp})$, Ireland ( $-27.5 \mathrm{pp})$ and Germany $(-27.2 \mathrm{pp})$. The most conservative countries in this respect were Hungary $(-0.6 \mathrm{pp})$ and France $(-3.4 \mathrm{pp})$ (Table 1).

However, when we look only at the recent period of 2010-2014, the change in EU-average CIT rate was only $-0.5 \mathrm{pp}$, with most countries showing no change during these years. The most significant reductions applied in United Kingdom (-7 pp), Finland ( $-6 \mathrm{pp})$ and Sweden $(-4.3 \mathrm{pp})$. Four countries increased their CIT rates: Slovak Republic (+3 pp), Cyprus (+2.5 pp), Greece (+2 pp) and Luxembourg (+0.6). Hungary makes a special case here: after the CIT rate went up from the initial 19.6 percent in 2007 , it got reduced to 16 percent in 2009 only to rise again in 2010 to reach 19 percent. This was mostly the effect of Hungary's problems with implementing the national fiscal policy.

From the comparison of the CIT rates offered and the ranking of economies by their competitiveness it can easily be inferred that it is not the tax burden (resulting from the effective tax rate), but other factors like the efficiency of public institutions, the transparency of public management or the quality of natural environment that secure any country's high position in the attractiveness ranking. As you can see, there is no simple relationship between the reduction of tax rates and the change of competitive position of the country. During the 2005-2014 period United Kingdom, despite a significant reduction in CIT rates did not change position in the GCI ranking, and the German did. By way of an example, if we rank EU countries by their CIT rates, the lowest rates are offered by Bulgaria and Cyprus while the highest by Malta and Belgium. However, when the GCI is used to build a competitiveness ranking, the most competitive economies are those of Finland, Germany and Sweden, and the least competitive ones - Greece and Slovak Republic (Table 2). 
Table 1

Corporate Income Tax Rates in EU countries (selected years)

\begin{tabular}{|c|c|c|c|c|c|c|c|c|}
\hline \multirow{2}{*}{ Country } & \multicolumn{8}{|c|}{ CIT Rates } \\
\hline & 1995 & 2000 & 2005 & 2010 & 2014 & $\begin{array}{c}\text { Change } \\
1995-2014\end{array}$ & $\begin{array}{c}\text { Change } \\
2005-2014\end{array}$ & $\begin{array}{c}\text { Change } \\
2010-2014\end{array}$ \\
\hline Austria & 34 & 34 & 25 & 25 & 25 & -9 & 0 & 0 \\
\hline Belgium & 40.2 & 40.2 & 34 & 34 & 34 & -6.2 & 0 & 0 \\
\hline Bulgaria & 40 & 32.5 & 15 & 10 & 10 & -30 & -5 & 0 \\
\hline Croatia & 25 & 35 & 20.3 & 20 & 20 & -5 & -0.3 & 0 \\
\hline Cyprus & 25 & 29 & 10 & 10 & 12.5 & -12.5 & 2.5 & 2.5 \\
\hline Czech Rep. & 41 & 31 & 26 & 19 & 19 & -22 & -7 & 0 \\
\hline Denmark & 34 & 32 & 28 & 25 & 24.5 & -9.5 & -3.5 & -0.5 \\
\hline \begin{tabular}{|l|} 
Estoniaa \\
\end{tabular} & 26 & 26 & 24 & 21 & 21 & -5 & -3 & 0 \\
\hline Finland & 25 & 29 & 26 & 26 & 20 & -5 & -6 & -6 \\
\hline Franceb & 36.7 & 36.7 & 35 & 33.3 & 33.3 & -3.4 & -1.7 & 0 \\
\hline Germanyb & 56.8 & 51.6 & 38.3 & 29.4 & 29.6 & -27.2 & -8.7 & 0.2 \\
\hline \begin{tabular}{|l|} 
Greece \\
\end{tabular} & 40 & 40 & 32 & 24 & 26 & -14 & -6 & 2 \\
\hline \begin{tabular}{|l} 
Hungary \\
\end{tabular} & 19.6 & 19.6 & 17.5 & 19 & 19 & -0.6 & 1.5 & 0 \\
\hline Ireland & 40 & 24 & 12.5 & 12.5 & 12.5 & -27.5 & 0 & 0 \\
\hline Italyb & 52.2 & 41.3 & 37.3 & 31.4 & 31.4 & -20.8 & -5.9 & 0 \\
\hline Latvia & 25 & 25 & 15 & 15 & 15 & -10 & 0 & 0 \\
\hline \begin{tabular}{|l|} 
Lithuania \\
\end{tabular} & 29 & 25 & 19 & 15 & 15 & -14 & -4 & 0 \\
\hline Luxembourg & 40.9 & 37.5 & 30.4 & 28.6 & 29.2 & -11.7 & -1.2 & 0.6 \\
\hline Malta & 35 & 35 & 35 & 35 & 35 & 0 & 0 & 0 \\
\hline \begin{tabular}{|l|} 
Netherlands \\
\end{tabular} & 35 & 35 & 31.5 & 25.5 & 25 & -10 & -6.5 & -0.5 \\
\hline \begin{tabular}{|l} 
Poland \\
\end{tabular} & 40 & 30 & 19 & 19 & 19 & -21 & 0 & 0 \\
\hline \begin{tabular}{|l|} 
Portugal \\
\end{tabular} & 39.6 & 37.4 & 27.5 & 25 & 23 & -16.6 & -4.5 & -2 \\
\hline Romania & 38 & 25 & 16 & 16 & 16 & -22 & 0 & 0 \\
\hline \begin{tabular}{|l|} 
Slovak Rep. \\
\end{tabular} & 40 & 29 & 19 & 19 & 22 & -18 & 3 & 3 \\
\hline Slovenia & 25 & 25 & 25 & 20 & 17 & -8 & -8 & -3 \\
\hline Spain & 35 & 35 & 35 & 30 & 30 & -5 & -5 & 0 \\
\hline Sweden & 28 & 28 & 28 & 26.3 & 22 & -6 & -6 & -4.3 \\
\hline United Kingdom & 33 & 30 & 30 & 28 & 21 & -12 & -9 & -7 \\
\hline Average EU-28 & 35,0 & 32,1 & 25,4 & 22,9 & 22,4 & -12.6 & -3.0 & -0.5 \\
\hline
\end{tabular}

${ }^{a}$ In Estonia, the tax rate on retained gains is 0 percent. ${ }^{\mathrm{b}}$ The tax rate also includes a local tax on business.

Source: KPMG's Corporate Tax Rate Survey 1993-2006, 2006; KPMG's Corporate and Indirect Tax Survey 2010, 2010; KPMG's Corporate and Indirect Tax Survey 2014, 2014. 
Rankings of the EU countries in the Global Competitiveness Index (GCI), selected years

\begin{tabular}{|c|c|c|c|c|c|}
\hline \multirow{2}{*}{ Country } & \multicolumn{5}{|c|}{ GCI } \\
\hline & $\begin{array}{l}\text { Rank } \\
\text { in } 2005\end{array}$ & $\begin{array}{l}\text { Rank } \\
\text { in } 2010\end{array}$ & $\begin{array}{l}\text { Rank } \\
\text { in } 2014\end{array}$ & $\begin{array}{c}\text { Change in rank } \\
2005-2014\end{array}$ & $\begin{array}{c}\text { Change in rank } \\
2010-2014\end{array}$ \\
\hline Austria & 17 & 18 & 16 & 1 & 2 \\
\hline Belgium & 20 & 19 & 17 & 3 & 2 \\
\hline Bulgaria & 72 & 71 & 57 & 15 & 14 \\
\hline Croatia & 51 & 77 & 75 & -24 & 2 \\
\hline Cyprus & 46 & 40 & 58 & -12 & -18 \\
\hline Czech Rep. & 29 & 36 & 46 & -17 & -10 \\
\hline Denmark & 4 & 9 & 15 & -11 & -6 \\
\hline Estonia & 25 & 33 & 32 & -7 & 1 \\
\hline Finland & 2 & 7 & 3 & -1 & 4 \\
\hline France & 18 & 15 & 23 & -5 & -8 \\
\hline Germany & 8 & 5 & 4 & 4 & 1 \\
\hline Greece & 47 & 83 & 91 & -44 & -8 \\
\hline Hungary & 41 & 52 & 63 & -22 & -11 \\
\hline Ireland & 21 & 29 & 28 & -7 & 1 \\
\hline Italy & 42 & 48 & 49 & -7 & -1 \\
\hline Latvia & 36 & 70 & 52 & -16 & 18 \\
\hline Lithuania & 40 & 47 & 48 & -8 & -1 \\
\hline Luxembourg & 22 & 20 & 22 & 0 & -2 \\
\hline Malta & 39 & 50 & 41 & -2 & 9 \\
\hline Netherlands & 9 & 8 & 8 & 1 & 0 \\
\hline Poland & 48 & 39 & 42 & 6 & -3 \\
\hline Portugal & 34 & 46 & 51 & -17 & -5 \\
\hline Romania & 68 & 67 & 76 & -8 & -9 \\
\hline Slovak Rep. & 37 & 60 & 78 & -41 & -18 \\
\hline Slovenia & 33 & 45 & 62 & -29 & -17 \\
\hline Spain & 28 & 42 & 35 & -7 & 7 \\
\hline Sweden & 7 & 2 & 6 & 1 & -4 \\
\hline United Kingdom & 10 & 12 & 10 & 0 & 2 \\
\hline
\end{tabular}

Source: The Global Competitiveness Report 2006-2007, 2006; The Global Competitiveness Report 2010-2011, 2010; The Global Competitiveness Report 2013-2014, 2013.

The countries which are keen to retain investors' interest with more friendly taxation earn more tax revenues from new investors despite lowering the tax burden, and this is attributable to the effect of scale. On the microeconomic scale the same effect is achieved by a business which earns huge profits despite a small profit margin. It manages to do so through large sales volumes, reached through offering good value for money.

However, we must remember that the income taxation level is not the most significant in making a national economy competitive. Countries which enjoy high-quality infrastructure, stable and transparent legal and tax systems and a large proportion of highly-qualified labour need not fear that investors will seek greener pastures and can keep their taxation relatively high. Conversely, the countries which are at 
a relatively lower level of development and have less capital offer lower taxation in compensation for their infrastructural shortcomings to remain at least moderately attractive for investors.

The flexibility and freedom of deciding their own income tax rates, enjoyed under the present legislation by the EU member countries guarantees a healthy environment for economic activity and fair competition between individual countries. This competition may be beneficial to all the market actors, provided that they make use of their opportunities.

\section{CONCLUSIONS}

Economic reality of contemporary world economy, particularly the progressing process of removing the barriers in the trade exchange and more and more big facilitation in the scope of the economic turnover between states, isn't indifferent to the business activity of enterprises. Intensification of the globalization process in the sphere of business, and especially the increasing mobility of the allocation of factors of production, forcing the government to offer to potential investors more favorable taxation and, therefore, creates a kind of "fight on taxes" and tax competition between countries.

Without fail, the diversification of tax systems, especially with regard to corporate income, requires companies to apply a significant range of knowledge and know-how to be able to function amidst the several tax systems operated within the European Union, which for smaller companies means huge extra costs and frequently undeserved losses. However, any attempt at harmonization of tax policies done in an arbitrary way, contrary to the freedom of economic activity, and consisting in harmonizing income tax rates through setting up a minimum rate or rate brackets would be harmful to growing economies and might pose a real threat to economic development.

The proposals in the field of harmonizing the corporate income taxation which involve defining a common consolidated corporate tax base (the CCCTB concept) may raise some fears and are even contested in some EU countries, but they seem more acceptable than the approaches based on a uniform tax rate.

Imposing too many legal restrictions, restraining economic development through state intervention and the creation of artificial barriers to the movement of labor, capital, etc., in the name of short-sighted benefits and interests of narrow groups and some countries at the expense of others, is a glaring example of measures to discourage entrepreneurs to economic activity, convictions them in the long term for the defeat in the race to take the best place in the world economy.

In conclusion it must be emphasized that a rational tax policy should manifest itself in determining the shape of such a tax system that would promote cost-effective initiatives, because the potential scale of the tax burden is an important element of the decision on the choice of an optimal location for doing business. Creating a friendly "tax climate" for domestic and foreign businesses become need of the hour. Any failure in this area can mean a loss of the high position of the economy in the world's economic rankings.

\section{REFERENCES}

Boyce J.K. (2004), Green and Brown? Globalization and the Environment, University of Massachusetts Amherst, Department of Economics, Working Papers, No. 2004-01.

Brouwer A.E., Mariotti I., van Ommeren J.N. (2002), The firm relocation decision: a logit model, European Regional Science Association conference papers, No. ersa02p205, p. 1.

Brzeziński B., Głuchowski J., Kosikowski C. (1998), Harmonizacja prawa podatkowego Unii Europejskiej i Polski, PWE, Warszawa. 
Council Directive on a Common Consolidated Corporate Tax Base (CCCTB), European Commission, Brussels, COM(2011) 121/4, 2011/0058 (CNS), p. 5.

Council Regulation (EC) No 1260/1999 of 21 June 1999 laying down general provisions on the Structural Funds (OJ L 161 of 26.6.1999).

Council Regulation (EC) No 1083/2006 of 11 July 2006 laying down general provisions on the European Regional Development Fund, the European Social Fund and the Cohesion Fund and repealing Regulation (EC) No 1260/1999 (OJ L 210 of 31.7.2006).

Devereux M.P., Hubbard R.G. (2000), Taxing Multinationals, NBER, Working Paper 7920, Cambridge.

Dicken P. (2008), Global Shift: Transforming the World Economy, London, Paul Chapman Publishing.

Employment in Europe 2004. Recent Trends and Prospects, (2004) European Commission, International Publications, Paper 36, p. 218.

European Commission and the CCCTB. Hard work ahead, Tax Policy and Controversy Briefing, Issue 6, Ernst\&Young// www.ey.com/IE/en/home (referred on 05/04/2011).

European Economic and Social Committee Opinion On Direct company taxation, (2002), ECO/091, CES 850/2002, Brussels 17.07.2002.

European Economic and Social Committee Opinion On the scope and effects of company relocations, (2005), OJ C 294/09 of 25.11 .2005 .

Gilroy B.M. (2001), Globalisation, multinational enterprises and European integration, University Library of Munich, MPRA Paper No. 17972 (http://mpra.ub.uni-muenchen.de/17972/).

Gorter J., Tang P., Toet M. (2005), Relocation from the Netherlands; motives, consequences and policy, CPB Document 76, Netherlands Bureau for Economic Policy Analysis.

Grigat H.-G. (1997), Verlagerung von Unternehmensgewinnen in das Ausland und Steuerdumping, in: WSI-Mitteilungen, no. 6, pp. $404-414$.

Gryko J.M., Kluzek M. (2008), The influence of the tax factor on investment effectiveness in selected Central and Eastern European countries, Transformations in Business \& Economics, Vol. 7, No. 3(15), Brno - Kaunas - Riga - Vilnius, pp. 65-74.

Holtz-Eakin D., Rosen H.S. (2001), Economic Policy and the Start-up, Survival, and Growth of Entrepreneurial Ventures, Small Business Administration Office of Economic Research, p. 24.

Implementing the Community Programme for improved growth and employment and the enhanced competitiveness of EU business: Further Progress during 2006 and next steps towards a proposal on the Common Consolidated Corporate Tax Base (CCCTB), (2007), European Commission COM(2007) 223 final Brussels, 2.5.2007.

Kawecka-Wyrzykowska E. (2007), Narodowe regulacje na rynku wewnętrznym UE: nowe bariery we wspótpracy, in: Unia Europejska w gospodarce światowej - nowe uwarunkowania, SGH, Warszawa.

Kopits G. (1992), Tax Harmonization in the European Community, Policy Issues and Analysis, International Monetary Fund, Occasionaly Paper, vol. 94, Washington DC, p.2.

KPMG's Corporate Tax Rate Survey 1993-2006, (2006) KPMG International //www.kpmg.com (referred on 12/02/2014).

KPMG's Corporate and Indirect Tax Survey 2010, (2010) KPMG International //www.kpmg.com (referred on 12/02/2014).

KPMG's Corporate and Indirect Tax Survey 2014, (2014) KPMG International //www.kpmg.com (referred on 12/02/2014).

Krajewska A., Krajewski S. (2007), Is Corporate Income Tax Harmonization Possible in an Enlarged European Union?, „Buletin Stiintific”, International Society for Intercommunication of New Ideas, p. 154.

Lanoo K., Levin M. (2002), An EU Company without an EU Tax? A Corporate Tax Action Plan for Advancing the Lisbon Process, CEPS Research Report.

Leamer, E.E. (1996), The Effects of Trade in Services, Technology Transfer and Delocalisation on Local and Global Income Inequality, Asia-Pacific Economic Review 2, pp.44-60.

Lodin S.-O., Gammie M. (1999), The Taxation of the European Company, European Taxation, pp. $286-294$. 
Małuszyńska E. (2006), Delokalizacja przedsiębiorstw, „Wspólnoty Europejskie”, nr 3 (172).

Mankiw N.G., Swagel P. (2005), The Politics and Economics of Offshore Outsourcing, American Enterprise Institute for Public Policy, Research Working Paper No. 122.

Mendoza E.G., Tesar L.L. (2005), Why hasn't tax competition triggered a race to the bottom? Some quantitative lessons from the EU? "Journal of Monetary Economics", vol. 52, pp.163-204.

Oręziak L. (2007), Konkurencja podatkowa i harmonizacja podatków w ramach Unii Europejskiej. Implikacje dla Polski, Wyższa Szkoła Handlu i Prawa im. Ryszarda Łazarkiewicza w Warszawie, Warszawa, p. 141.

Pennings E., Sleuwaegen L., Monmaerts G. (2000), Relocation, an Element of Industrial Dynamics, Synthesis Report. Brussels: Federal Planning Bureau, pp. 4-5.

Report of the Committee of Independent Experts on Company Taxation, (1992) Commission of the European Communities Office for Official Publications of the European Communities, Luxembourg.

Request of input from national tax administrations for the Impact Assessment of the reforms at the EU level of corporate tax systems, (2008), Common Consolidated Corporate Tax Base Working Group (CCCTB WG), CCCTB।WP\067, Brussels, 2.4.2008.

Rodrik D. (1998), Globalisation, Social Conflict and Economic Growth, in: The World Economy, vol. 21, Issue 2, pp. 143-158.

Schratzenstaller M. (2000), Corporate Taxation in Europe - Possibilities, Problems and Options for Reform, Network of Alternative Economists in Europe, Workshop in Stockholm, April 7th to 9th 2000, Working Paper, No. II/29.

Sepp J., Wróbel R.M. (2003), Tax Competition and EU Enlargement: Strategies within a Developing Political-Economic Environment. In Essays in Estonian Transformation Economics, ed. U. Ennuste and L. Wilder. Estonian Institute of Economics at Tallinn Technical University.

Stern R.M., Deardorff A.V. (2006), Globalization's bystanders: Does trade liberalization hurt countries that do not participate? World Development, Elsevier, vol. 34(8), pp. 1419-1429.

The Global Competitiveness Report 2006-2007, (2006), World Economic Forum, Geneva // www.weforum.org (referred on $12 / 02 / 2014)$.

The Global Competitiveness Report 2010-2011, (2010), World Economic Forum, Geneva // www.weforum.org (referred on $12 / 02 / 2014)$.

The Global Competitiveness Report 2013-2014, (2013), World Economic Forum, Geneva // www.weforum.org (referred on $12 / 02 / 2014)$.

Thompson R.L. (2007), Globalization and the benefits of trade, „Chicago Fed Letter”, The Federal Reserve Bank of Chicago, No. 236.

Tiebout C. (1956), A pure theory of local expenditures, „Journal of Political Economy”, vol. 64, pp. 416-424.

Towards an Internal Market without tax obstacles. A strategy for providing companies with a consolidated corporate tax base for their EU-wide activities, (2001) European Commission COM(2001) 582 final, Brussels, 23.10.2001.

Van Dijk J., Pellenbarg P.H. (1999), Demography of firms; spatial dynamics of firm behaviour, Netherlands Geographical Studies, No. 262, University of Groningen.

Van Dijk J., Pellenbarg P.H. (2000), Firm relocation decisions in The Netherlands: An ordered logit approach, Papers in Regional Science, Springer, vol. 79(2), pp. 191-219.

Wdowicka M. (2009), Ewolucja dziatania korporacji transnarodowych i jej znaczenie w gospodarce lokalnej, Biuletyn Instytutu Geografii Społeczno-Ekonomicznej i Gospodarki UAM, Seria Rozwój Regionalny i Polityka Regionalna, No. 6 Wybrane problemy miast i aglomeracji miejskich na początku XXI w., red. Parysek J.J. (red.), Bogucki Wydawnictwo Naukowe, Poznań, pp. 73-74. 